\title{
Study on Proteolytic Potential of Buffalo Milk Using Lactococcus Lactis Ssp. Cremoris and Lactococcus Lactis Ssp. Lactis
}

\author{
Lokesh Tak $^{1}$, Basant Bais ${ }^{1 *}$, Raghvendar Singh ${ }^{2}$, C. S. Dhaka ${ }^{1}$ and Sanjay Singh ${ }^{1}$ \\ ${ }^{1}$ Department of Livestock Products Technology, College of Veterinary and Animal Science, India \\ ${ }^{2}$ National Research Centre on Camel, India
}

Submission: July 19, 2017; Published: September 27, 2017

*Corresponding author: Basant Bais, Department of Livestock Products Technology, College of Veterinary and Animal Science, Rajasthan University of Veterinary and Animal Sciences, Bikaner- 334001, Rajasthan, India, Email: basantbais@gmail.com

Abstract

The present investigation was designed to determine proteolytic potential of lactic acid bacteria (LAB) wiz. Lactococcus lactis ssp. cremoris and Lactococcus lactis ssp. Lactis at different time interval for a period of 12 hours. Study revealed that pH value and its rate of decrement was higher in samples, which are fermented with Lactococcus lactis ssp. cremoris comparing with Lactococcus lactis ssp. lactis, in buffalo milk samples.

\section{Introduction}

Buffalo milk contains all the nutrients in higher proportions than cow milk as per the nutrient components. The compositional differences between buffalo and cow milk are reflected on their physico-chemical properties. Milk from buffalo preferred for preparing dairy products of western and traditional (indigenous) type and nutritionally superior. Buffalo milk contains less cholesterol (total cholesterol $275 \mathrm{mg}$ and free cholesterol 212 mg per $100 \mathrm{~g}$ of fat) in compared to cow milk (total cholesterol $330 \mathrm{mg}$ and free cholesterol $280 \mathrm{mg}$ per $100 \mathrm{~g}$ of fat) and more

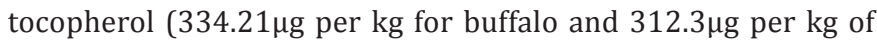
cow milk). Due to high peroxidase activity, buffalo milk can be preserved naturally for a longer period. Buffalo milk contains more calcium, better calcium: phosphorous ratio and less sodium and potassium than cow milk which makes it a better nutritional supplement for infants.

Due to growth requirements, dairy starter cultures have developed highly sophisticated proteolytic system that capable of break down milk proteins, mainly $\alpha 1$ and $\beta$-caseins. The proteolytic structure of lactic acid bacteria (LAB) and their activities in dairy products including yogurt and cheese have been studied extensively [1-5].

Lactococcus lactis has two subspecies with few phenotype and genotype differences, Lactococcus lactis ssp. lactis and ssp. cremoris, where subsp. lactis is preferred for making soft cheese while subsp. Cremoris is for hard cheese.

\section{Material and methods}

\section{Periodical evaluation of fermented buffalo milk}

Fresh buffalo milk was skimmed to bring the fat contents to below $0.5 \%$ using cream separator. The samples were heated to boil at least for $5 \mathrm{~min}$ to inactivate/kill the inherent microbial population present in milk. Then Lactococcus lactis ssp. cremoris and Lactococcus lactis ssp. lactis cultures were inoculated @ 1\% and after proper mixing, the samples were inoculated at $30{ }^{\circ} \mathrm{C}$ .The samples were drawn at $0,2,4,6,8,10,12$ hours and were subjected to analysis for change in $\mathrm{pH}$.

\section{Bacterial cultures and their propagation}

Glass ampoules containing Lyophilized powder of Lactococcus lactis ssp. cremoris NCDC 81 and Lactococcus lactis ssp. lactis NCDC 88 were obtained from the NCDC (National Collection of Dairy Cultures) Dairy Microbiology Division ICAR-National Dairy Research Institute, Karnal (INDIA). The organisms were stored at $4{ }^{\circ} \mathrm{C}$. The propagation for each strain was performed according to Donker et al., [1] with slight modification. Sterile $5 \mathrm{ml}$ aliquots of reconstituted sterile skim milk (RSM) (Himedia Laboratories) were inoculated with each strain individually and incubated at $30{ }^{\circ} \mathrm{C}$ for $24 \mathrm{~h}$ in BOD incubator. After incubation, the pre-inoculated cultures were prepared by transferring loop full of activated culture to $10 \mathrm{ml}$ aliquots of litmus milk (Himedia Laboratories) to determine the activation of culture 
activity by observing change in color of litmus milk after 24 hour of inoculation Figure 1. The skim milk and litmus milk were autoclaved following the standard procedure $\left(121^{\circ} \mathrm{C}\right.$ for $15 \mathrm{~min}$ @15lbs).

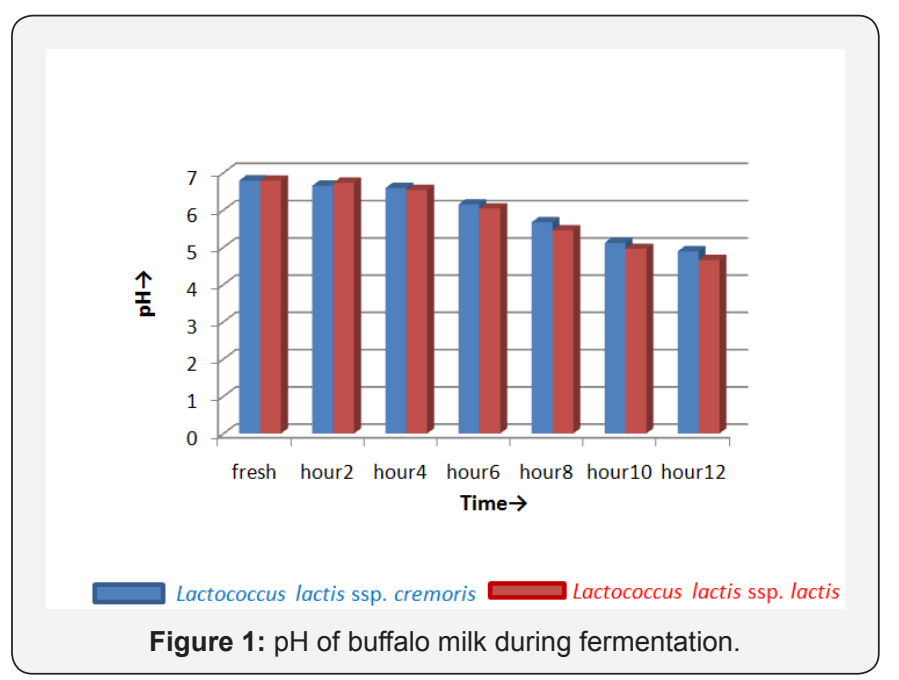

\section{pH measurement of milk samples:}

The $\mathrm{pH}$ of samples was measured by using combined glass electrode of Milkoscan at camel milk research laboratory, ICARNRC on Camel, Bikaner.

\section{Result and Discussion}

\section{Change in $\mathrm{pH}$ during hydrolysis:}

Table 1: $\mathrm{pH}$ (Mean \pm SE) of buffalo milk during fermentation.

\begin{tabular}{|c|c|c|}
\hline Treatment & $\begin{array}{c}\text { Lactococcus lactis ssp. } \\
\text { cremoris }\end{array}$ & $\begin{array}{c}\text { Lactococcus lactis ssp. } \\
\text { lactis }\end{array}$ \\
\hline Fresh & $6.79 \pm 0.007$ & $6.79 \pm 0.004$ \\
\hline Hour 2 & $6.73 \pm 0.003$ & $6.65 \pm 0.005$ \\
\hline Hour 4 & $6.53 \pm 0.003$ & $6.59 \pm 0.006$ \\
\hline Hour 6 & $6.04 \pm 0.009$ & $6.15 \pm 0.005$ \\
\hline Hour 8 & $5.45 \pm 0.010$ & $5.67 \pm 0.006$ \\
\hline Hour 10 & $4.96 \pm 0.007$ & $5.12 \pm 0.005$ \\
\hline Hour 12 & $4.66 \pm 0.011$ & $4.89 \pm 0.004$ \\
\hline Overall & $5.88 \mathrm{a} \pm 0.126$ & $5.98 \mathrm{~b} \pm 0.111$ \\
\hline
\end{tabular}

Note - Means bearing different superscripts within a row differ significantly.

The data related to $\mathrm{pH}$ of buffalo milk has been shown in Table 1 .The $\mathrm{pH}$ of fresh milk was found to be $6.79 \pm 0.004$ for Lactococcus lactis ssp. cremoris and $6.79 \pm 0.007$ for Lactococcus lactis ssp. lactis before inoculation of treated bacteria.

The value of $\mathrm{pH}$ was dropped significantly as the fermentation hour were increased and at 12 hour of fermentation and it was observed to be $4.89 \pm 0.004$ and $4.66 \pm 0.011$ for Lactococcus lactis ssp. cremoris and Lactococcus lactis ssp. lactis respectively whereas the overall $\mathrm{pH}$ was $5.98 \pm 0.111$ and $5.88 \pm 0.126$ for Lactococcus lactis ssp. cremoris and Lactococcus lactis ssp. lactis respectively. The $\mathrm{pH}$ value demonstrated in Table 1 reveals that the rate of decrement was higher in samples, which are fermented with Lactococcus lactis ssp. cremoris comparing with Lactococcus lactis ssp. lactis, in buffalo milk samples. [6,7].

Process of fermentation is affected by several factors including the structure of the protein, temperature, enzyme/ protein ratio, enzyme concentration and $\mathrm{pH}$. In the present study, almost linear drop in $\mathrm{pH}$ was observed during the fermentation process in buffalo milk samples. The release of protons (H+ ion) and/or production of acidic amino acids into the surrounding medium results in reduction in the $\mathrm{pH}$ of the reaction mixture.

Table 2: Analysis of variance for $\mathrm{pH}$ of buffalo milk during fermentation.

\begin{tabular}{|c|c|c|c|}
\hline Source of variation & D.F. & Mean Square & Level of sig. \\
\hline Treated bacteria & 1 & 0.207 & $* *$ \\
\hline Hour & 6 & 8.034 & $* *$ \\
\hline Reminder & 76 & 0.003 & \\
\hline
\end{tabular}

** $=$ Significant at $1 \%(P<0.01)$.

The statistical analysis of data as shown in Table 2, revealed that there was a highly significant $(\mathrm{P}<0.01)$ decrease in the $\mathrm{pH}$ value of buffalo milk samples with advancement of fermentation hours as well as between the treated bacteria that is Lactococcus lactis ssp. cremoris and Lactococcus lactis ssp. lactis. [8,9].

\section{References}

1. Shah NP, Ravula RR (2000) Micro encapsulation of probiotic bacteria and their survival in frozen fermented dairy desserts. Australian Journal of Dairy Technology 55(3): 139-144.

2. Shalash MR (1979) Utilization of camel meat and milk in human nourishment. Provisional Report, International Foundation for Science 6: pp.285-306.

3. Hernandez D, Cardell E, Zarate V (2005) Antimicrobial activity of lactic acid bacteria isolated from Tenerife cheese: initial characterization of plantaricin TF711, a bacteriocin-like substance produced by Lactobacillus plantarum TF711. J Appl Micro 99(1): 77-84.

4. Lourens HA, Viljoen BC (2001) Yogurt as probiotic carrier food. Int dairy j 11(1): 1-17.

5. Donkor ON, Henriksson A, Vasiljevic T, Shah NP (2007) Proteolytic activity of dairy lactic acid bacteria and probiotics as determinant of growth and in vitro angiotensin-converting enzyme inhibitory activity in fermented milk. Lait 86: 21-38.

6. Rao MB, Gupta RC, Dastur NN (1970) Camels' milk and milk products. Ind J Dairy Sci 23: 71-78.

7. Minieri L, De Franciscis G, Intrieri F (1965) On behavior of pH value in relation to acidity and chemical constituents of milk: research in Bubalus buffalus. Acta Med Vet (Napoli) 11(1): 107-114.

8. Pan D, Luo Y, Tanokura M (2005) Antihypertensive peptides from skimmed milk hydrolysate digested by cell-free extract of Lactobacillus helveticus JCM1004. Food Chemistry 91(1): 123-129.

9. Gomes AMP, Malcata FX (1999) Bifidobacterium spp. and Lactobacillus acidophilus: biological, biochemical, technological and therapeutically properties relevant for use as probiotics. Trends in Food Science \& Technology 10: 139-157. 
This work is licensed under Creative Commons Attribution 4.0 Licens DOI: 10.19080/JDVS.2017.03.555625
Your next submission with Juniper Publishers will reach you the below assets

- Quality Editorial service

- Swift Peer Review

- Reprints availability

- E-prints ServiceManuscript Podcast for convenient understanding

- Global attainment for your research

- Manuscript accessibility in different formats

( Pdf, E-pub, Full Text, Audio)

- Unceasing customer service

Track the below URL for one-step submission https://juniperpublishers.com/online-submission.php 